\title{
FORMULASI SEDIAAN TABLET PARASETAMOL DENGAN PATI \\ BUAH SUKUN (Artocarpus communis) SEBAGAI PENGISI
}

\author{
Dwi Elfira Kurniati*, Mirhansyah Ardana, Rolan Rusli \\ Laboratorium Penelitian dan Pengembangan FARMAKA TROPIS, Fakultas \\ Farmasi Universitas Mulawarman, Samarinda, Kalimantan Timur \\ *Email: dwielfira.kurniati@yahoo.com
}

\begin{abstract}
ABSTRAK
Penggunaan pati sebagai bahan pengisi umum digunakan dalam pembuatan tablet guna menyempurnakan bentuk tablet. Penelitian ini bertujuan untuk memformulasi dan mengevaluasi kualitas granul dan sifat fisik sediaan tablet parasetamol menggunakan pati sukun sebagai bahan. Pati dibuat dengan cara dekantasi dan pengeringan. Empat formula sediaan tablet (F1, F2, F3, dan F4) dibuat menggunakan metode granulasi basah dengan bobot 575mg (F1), 600mg (F2), 650mg (F3), dan 700mg (F4) dengan menggunakan pati sebesar 4,3\% (F1), 8,3\% (F2), 15,3\% (F3), dan 21,4\% (F4). Evaluasi kualitas granul, meliputi pengujian laju alir, sudut istirahat, densitas dan indeks kompresibilitas. Sedangkan evaluasi sifat fisik tablet meliputi pengujian keseragaman ukuran, keseragaman bobot, waktu hancur dan friabilitas. Hasil penelitian menunjukkan bahwa evaluasi kualitas granul memenuhi persyaratan laju alir, sudut istirahat, dan indeks kompresibilitas, tetapi tidak memenuhi syarat distribusi ukuran partikel. F1 dan F2 dapat dikempa. F2 tidak memenuhi syarat friabilitas namun memenuhi syarat keseragaman bobot, ukuran dan waktu hancur. F1 memenuhi semua syarat uji sifat fisik tablet
\end{abstract}

Kata Kunci: Pati, sukun (Artocarpus communis), bahan pengisi, tablet, Parasetamol

\section{PENDAHULUAN}

Penggunaan pati sebagai bahan pengisi umum digunakan dalam formulasi sediaan tablet guna menyempurnakan bentuk tablet. Bahan pengisi yang paling umum digunakan adalah pati, laktosa dan dekstrosa. Pati terdapat dalam umbiumbian seperti singkong, ubi ungu, kentang dan sukun.

Sukun (Artocarpus communis) merupakan sumber pati alami yang mudah dalam pengolahannya dan terdapat banyak di wilayah Indonesia. Menurut Prasesti 
dkk, (2016), pati sukun dapat digunakan sebagai bahan pengisi, penghancur dan pengikat pada sediaan tablet.

Tablet adalah bentuk sediaan padat yang mengandung satu unit dosis lazim, dengan satu macam bahan aktif atau lebih tergantung tujuan terapi yang dicapai. Tablet berbentuk bulat datar atau bikonvek (Sulaiman, 2007). Selain mengandung bahan aktif, tablet biasanya mengandung bahan tambahan yang mempunyai fungsi tertentu. Bahan tambahan yang umum digunakan adalah bahan pengisi, bahan pengikat, bahan pengembang, bahan pelicin atau zat lain yang cocok.

Menurut Ditjen POM (2015), Parasetamol sukar larut dalam air dingin. Sifat parasetamol tersebut membuatnya sukar untuk diformulasikan dalam bentuk larutan. Selain itu sifat alir parasetamol kurang baik sehingga sulit untuk membuat tablet cetak langsung dan membutuhkan bahan tambahan yang sesuai. Oleh karena itu peneliti akan memformulasikan tablet parasetamol menggunakan pati sukun (Artocarpus communis) sebagai bahan pengisi.

\section{METODE PENELITIAN}

\section{Bahan}

Bahan yang digunakan dalam penelitian ini adalah Pati Sukun (Artocarpus communis), Parasetamol BPFI, Polivinilpirolidon, Magnesium stearat, talkum, $\mathrm{KH}_{2} \mathrm{PO}_{4}, \mathrm{NaOH}$, Aquades, Metanol.

\section{Peralatan}

Alat-alat yang digunakan dalam penelitian ini adalah toples kaca, oven, timbangan analitik, stopwatch, labu ukur, gelas kimia, batang pengaduk, mikro pipet, mortir dan stemper, loyang, ayakan mesh 20, penggaris, flow tester, volumeter, friabilator, dissolution tester, spektrofotometer UV, $\mathrm{pH}$ meter, thermometer, blender, alat pencetak tablet.

\section{Prosedur}

\section{Pembuatan Pati}

Pembuatan pati dilakukan dengan cara dekantasi. Pertama dikupas kulit buah sukun lalu dibersihkan, dipotong buah sukun kecil-kecil kemudian dihaluskan, proses penghalusan dilakukan dengan penambahan air agar mempermudah alat 
bekerja. Disaring supernatan dari bubur buah sukun yang telah dihaluskan, kemudian diendapkan selama 24 jam. Diambil endapan yang terdapat pada bagian bawah toples, lalu diletakkan diatas loyang dan dikeringkan didalam oven suhu $60^{\circ}$ selama \pm 6 jam.

\section{Pembuatan Tablet}

Ditimbang semua bahan yang akan digunakan sesuai dengan perhitungan pada setiap formula. Dicampur bahan aktif dengan bahan pengisi yaitu Parasetamol dan pati sukun. Kemudian dibuat pasta dari polivinilpirolidon yang berfungsi sebagai pengikat. Lalu dicampurkan pasta kedalam campuran sampai terbentuk masa yang baik untuk digranulasi. Lalu dibuat granul dengan menggunakan ayakan mesh 20. Di ratakan granul yang telah jadi lalu di oven dengan suhu $60{ }^{\circ} \mathrm{C}$ selama \pm 2 jam. Didinginkan granul lalu digranulasi kering menggunakan ayakan mesh 20 . Kemudian ditimbang granul yang dihasilkan. Ditambahkan fase luar berupa talkum dan Mg. stearat. Lalu dicetak tablet menggunakan alat pencetak tablet.

\section{Pengujian Evaluasi Kualitas granul}

\section{Laju Alir}

Dimasukkan 20 gram granul kedalam corong flow tester, dibuka penutup corong dan dihitung waktu alir granul yang jatuh dari corong pada permukaan bidang datar alat.

\section{Sudut Istirahat}

pengujian sudut istirahat dilakukan bersamaan dengan uji laju alir. Diameter dan tinggi gundukan yang dihasilkan diukur dan dihitung menggunakan rumus:

$$
\tan \varnothing=\frac{2 h}{D}
$$

keterangan:

$\emptyset=$ sudut diam

$\mathrm{H}=$ tinggi tumpukan granul $(\mathrm{cm})$

$\mathrm{D}=$ diameter tumpukan granul $(\mathrm{cm})$ 


\section{Densitas}

Densitas ruahan yang ditentukan dari volum ruahan dan berat suatu serbuk kering dalam sebuah gelas ukur. Densitas terdiri dari bulk density dan tapped density yang dapat dihitung dengan rumus:

$$
\begin{aligned}
& \text { Bulk density }=\frac{\text { berat granul }(\mathrm{g})}{\text { volume bulk }(\mathrm{mL})} \\
& \text { Tap density }=\frac{\text { berat granul }(\mathrm{g})}{\text { volume tapped }(\mathrm{mL})}
\end{aligned}
$$

\section{Indeks kompresibilitas}

Kompresibilitas adalah kemampuan pembentukan massa yang stabil dan utuh ketika diberikan tekanan. Kompresibilitas dapat dihitung menggunakan rumus:

$$
\mathrm{IK}=\frac{(\text { tapped density-bulk density) }}{\text { bulk density }} \times 100 \%
$$

\section{Distribusi Ukuran Partikel}

Distribusi ukuran partikel dapat dilakukan mengunakan metode ayakan, ayakan disusun bertingkat dengan ukuran partikel yang besar berada pada posisi paling atas dan paling kecil berada pada posisi bawah. Mesh yang digunakan adalah mesh 20, 40, 60, 80, dan 100.

\section{Pengujian Sifat Fisik Tablet}

\section{Keseragaman Ukuran}

Uji keseragaman ukuran dilakukan menggunakan 10 tablet lalu diukur ketebalan dan diameter tablet menggunakan mikrometer sekrup. Persyaratan untuk ukuran tablet menurut Ditjen POM (1979), diameter tablet tidak lebih dari 3 kali dan tidak kurang dari $1 /$ kali tebal tablet. 


\section{Keseragaman Bobot}

Ditimbang 20 tablet dan dibersihkan dari debu, hitung bobot rata-rata kemudian timbang satu persatu dan diambil yang bervariasi tinggi. Persyaratan: Tidak satu tablet pun yang bobotnya menyimpang lebih besar dari bobot rata-rata A dan tidak satu tablet pun yang menyimpang lebih besar dari bobot rata-rata B (Ditjen POM, 1979).

\section{Friabilitas}

Kerapuhan dapat dievaluasi dengan menggunakan friabilator. Tablet yang akan diuji sebanyak 20 tablet, terlebih dahulu dibebas debukan dan ditimbang. Tablet tersebut selanjutnya dimasukkan ke dalam friabilator, dan diputar sebanyak 100 putaran (4 menit). Friabilitas dapat dihitung dengan rumus:

$$
\frac{W 1-W 0}{W 0} \times 100 \%
$$

\section{Waktu hancur}

Pengujian dilakukan terhadap 6 tablet. Dimasukkan 1 tablet pada masingmasing tabung dari keranjang, dimasukkan satu cakram pada tiap tabung, kemudian alat dijalankan. Digunakan air dengan suhu $37^{\circ} \pm 2{ }^{\circ} \mathrm{C}$ sebagai media. Persyaratan: Waktu yang diperlukan untuk menghancurkan tablet tidak lebih dari 15 menit untuk tablet tidak bersalut ( Ditjen POM, 2015 ).

\section{Pengujian Penetapan Kadar}

Pengujian kadar dilakukan menggunakan metode spektroskopi. Pertama dibuat kurva baku menggunakan parasetamol BPFI dengan seri konsentrasi 5ppm, 10ppm, 15ppm, 20ppm, dan 25ppm. Diukur panjang gelombang maksimum antara 200-400 nm. Dibuat larutan uji sampel F1 dan F2 diukur absorbansi masing-masing mengunakan panjang gelombang maksimum lalu dihitung kadar parasetamol menggunakan regresi linear.

\section{Pengujian Disolusi Tablet}

Uji disolusi tablet dilakukan menggunakan alat dissolution tester. Pertama dibuat larutan dapar fosfat $\mathrm{pH}$ 5,8 menggunakan $\mathrm{KH}_{2} \mathrm{PO}_{4}$ dan $\mathrm{NaOH}$ sebanyak 6 L. dibuat kurva baku parasetamol menggunakan pelarut dapar, dengan seri 
konsetrasi 5 ppm, 10 ppm, 15 ppm, 20 ppm, 25 ppm. Diukur panjang gelombang maksium .

Dimasukkan $900 \mathrm{~mL}$ dapar kedalam masing-masing labu. Diatur suhu pengujian $37{ }^{\circ} \mathrm{C} \pm 2{ }^{\circ} \mathrm{C}$ dan perputaran $50 \mathrm{rpm}$. Dimasukkan tablet pada masingmasing labu lalu dijalankan alat dan diambil larutan sampel pada waktu ke 5, 10, 15, dan 30 menit. Kemudian diukur absorbansi sampel menggunakan spektrofotometer UV dengan panjang gelombang $248 \mathrm{~nm}$.

\section{HASIL DAN PEMBAHASAN}

\section{Evaluasi Kualitas Granul}

\section{Laju Alir}

Laju alir yang baik adalah 100 gram serbuk dengan laju alir $\leq 10$ detik atau mempunyai laju alir $\geq 10$ gram/detik (Sulaiman, 2007). Faktor-faktor yang mempengaruhi laju alir adalah sifat-sifat granul yaitu ukuran partikel, distribusi ukuran partikel dan kelembaban (Lachman,2008). Berdasarkan tabel 1. terlihat bahwa keempat formula memiliki laju alir yang cukup baik. Hal ini disebabkan ukuran granul yang cenderung besar sehingga dapat meningkatkan laju alir. Partikel-partikel yang relatif besar memiliki gaya kohesi yang kecil sehingga laju aliran akan semakin mudah sedangkan ukuran partikel kecil akan meningkatkan gaya kohesi dan memperburuk laju alir (Sinko,2011).

Tabel 1. Hasil Evaluasi Kualitas Granul

\begin{tabular}{cccccc}
\hline Formula & \multicolumn{5}{c}{ Pengujian } \\
\cline { 2 - 6 } & $\begin{array}{c}\text { Laju alir } \\
(\text { gram/detik) }\end{array}$ & $\begin{array}{c}\text { Sudut } \\
\text { Diam } \\
(\mathbf{0})\end{array}$ & $\begin{array}{c}\text { Bulk } \\
\text { density } \\
(\mathrm{g} / \mathrm{mL})\end{array}$ & $\begin{array}{c}\text { Tap } \\
\text { density } \\
(\mathrm{g} / \mathrm{mL})\end{array}$ & $\begin{array}{c}\text { Kompresibilitas } \\
(\boldsymbol{\%})\end{array}$ \\
\hline 1 & 12,65 & 23,49 & 0,436 & 0,470 & 5,22 \\
2 & 14,40 & 25,24 & 0,505 & 0,555 & 9,99 \\
3 & 17,81 & 26,12 & 0,454 & 0,503 & 10,60 \\
4 & 13,47 & 20,50 & 0,276 & 0,307 & 11,00 \\
\hline
\end{tabular}




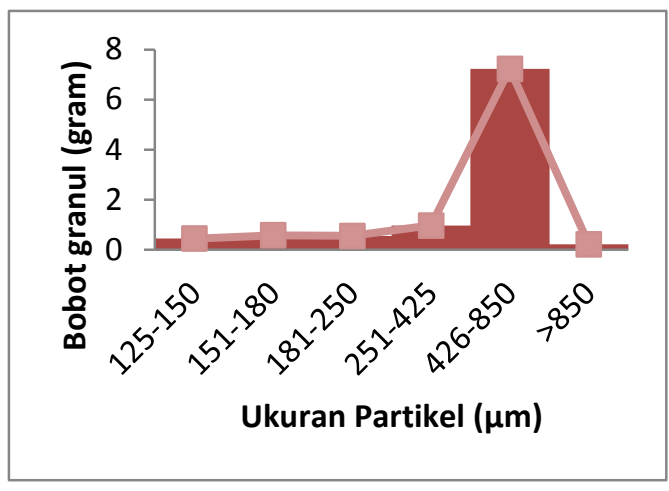

Gambar 1. Distribusi partikel F1

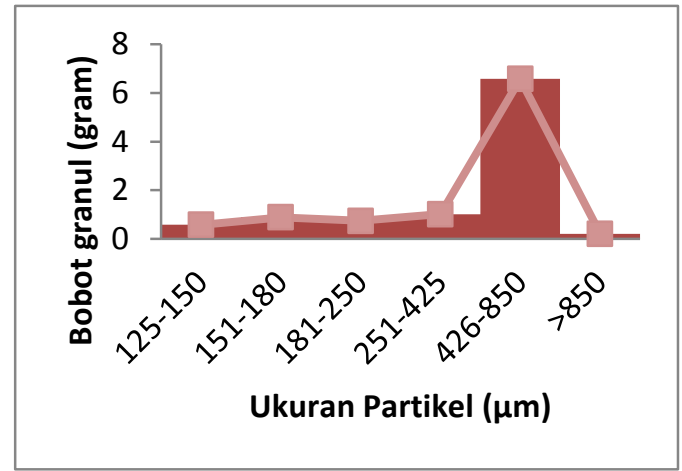

Gambar 3. Distribusi partikel F3

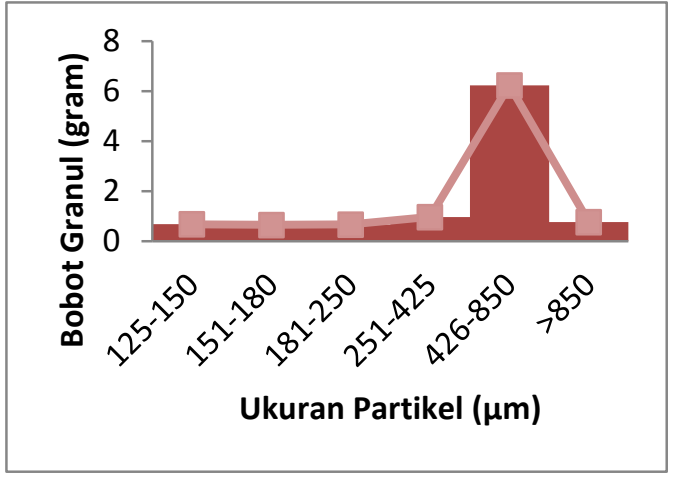

Gambar 2. Distribusi Partikel F2

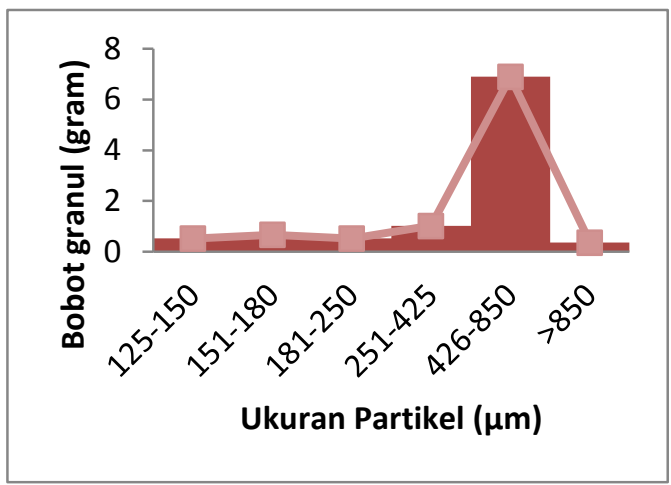

Gambar 4. Distribusi Partikel F4

\section{Sudut Istirahat}

Sudut istirahat adalah sudut yang terjadi antara permukaan gundukan serbuk dan bidang horizontal. Sudut istirahat yang baik adalah antara $20^{\circ}-45^{\circ}$, namun kecepatan alir sangat baik $<20^{\circ}$ (Sinko, 2011).

Berdasarkan tabel 6.2 terlihat bahwa semua formula memasuki rentang dan sesuai dengan persyaratan yaitu cukup baik. Hasil tersebut diduga terjadi akibat ukuran partikel yang relatif besar dan gaya kohesi yang dihasilkan kecil sehingga laju alir cenderung cukup baik.

\section{Densitas}

Nilai bulk density dan tapped density digunakan untuk mengukur laju alir dan indeks kompresibilitas granul. Nilai bulk density menunjukkan sifat alir suatu granul, dimana semakin besar bulk density maka semakin besar laju alir. Sementara nilai tapped density berpengaruh terhadap nilai kompresibilitas, dimana semakin mampat granul maka semakin baik nilai kompresibilitas granul (Aulton, 2001). 


\section{Indeks Kompresibilitas}

Uji Indeks kompresibilitas berfungsi untuk memprediksi sifat alir dari suatu granul (Gad, 2008). Menurut Ansel (2010), kompresibilitas yang baik akan menghasilkan tablet yang baik serta kompak. Faktor yang mempengaruhi kompresibilitas adalah adanya pembasahan granul yang dapat meningkatkan kompresibilitas. Bentuk dan tekstur partikel dapat mempengaruhi kompresibilitas yang baik.

Berdasarkan tabel diatas dapat dilihat bahwa semua formula memenuhi syarat untuk nilai kompresibilitas, dimana nilai kompresibilitas yang baik yaitu <20\% (Lachman dan Lieberman, 2008).

Tabel 2. Hasil Uji Sifat Fisik Tablet

\begin{tabular}{|c|c|c|c|c|c|}
\hline \multirow{3}{*}{ Formula } & \multicolumn{5}{|c|}{ Pengujian } \\
\hline & \multicolumn{2}{|c|}{$\begin{array}{c}\text { Keseragaman ukuran } \\
(\mathbf{m m})\end{array}$} & \multirow[t]{2}{*}{$\begin{array}{c}\text { Keseragaman } \\
\text { bobot (mg) }\end{array}$} & \multirow{2}{*}{$\begin{array}{c}\text { Kerapuhan } \\
\text { tablet } \\
\text { (gram) }\end{array}$} & \multirow{2}{*}{$\begin{array}{l}\text { Waktu } \\
\text { hancur } \\
\text { (menit) }\end{array}$} \\
\hline & Diameter & Ketebalan & & & \\
\hline 1 & $12,033 \pm 0,016$ & $6.428 \pm 0,021$ & $573,3 \pm 5,63$ & $4,793 \pm 2,386$ & $2,50 \pm 0,45$ \\
\hline 2 & $12,065 \pm 0,006$ & $5,931 \pm 0,043$ & $600,2 \pm 2,97$ & $0,151 \pm 0,130$ & $4,39 \pm 1,14$ \\
\hline
\end{tabular}

\section{Distribusi Ukuran Partikel}

Berdasarkan grafik diatas F1, F2, F3, dan F4 tergolong memiliki distribusi ukuran partikel agak besar dengan rentang 426-850 $\mu \mathrm{m}$ atau dengan ukuran mesh antara mesh 20 dan mesh 40. Hal ini terjadi kemungkian karena proses granulasi dilakukan dengan menggunakan ayakan mesh 20 sehingga granul yang terbentuk dominan berada pada ukuran rentang tersebut. Namun granul yang terbentuk tidak terdistribusi merata. Distribusi ukuran partikel yang baik adalah memiliki grafik histogram yang berbentuk lonceng, dalam artian ukuran partikel baik ketika tidak dominan pada satu ukuran saja. Seperti data yang didapatkan ukuran granul dominan pada rentang ukuran 426-850 $\mu \mathrm{m}$. 


\section{Pengujian Sifat Fisik Tablet}

\section{Uji Keseragaman Ukuran}

Berdasarkan tabel diatas diameter dan ketebalan tablet memenuhi syarat keseragaman ukuran. Syarat keseragaman ukuran menurut Menurut Farmakope Indonesia IV, syarat keseragaman ukuran kecuali dinyatakan lain, diameter tablet tidak lebih dari 3 kali dan tidak kurang dari $1 \frac{1}{3}$ kali tebal tablet. Ketebalan tablet dipengaruhi oleh beberapa hal yaitu tekanan pada saat mencetak tablet, jumlah massa yang diisikan pada ruang cetak tablet dan kerapatan massa tablet yang dicetak (Lachman, 2008) sedangkan diameter tablet dipengaruhi oleh ukuran ruang cetak tablet (Voight, 1994). Keseragaman ukuran berhubungan dengan laju alir, laju alir yang baik akan membuat granul lebih mudah melewati perlintasan die dan membuat granul memenuhi ruang die dengan tepat.

\section{Keseragaman Bobot}

Berdasarkan hasil yang didapatkan baik F1 maupun F2 masih memenuhi persyaratan keseragaman bobot tablet dimana persyaratan untuk tablet dengan bobot rata-rata $>300 \mathrm{mg}$ tidak boleh 2 tablet yang bobotnya menyimpang lebih dari 5\% dari bobot rata-rata dan tidak satupun tablet yang bobotnya menyimpang lebih dari 10\% dari bobot rata-rata (DepKes RI,1995). Hal ini diduga karena laju alir dari granul tergolong cukup baik sehingga bobot granul yang masuk kedalam ruang cetak sesuai dengan bobot yang diinginkan. Namun F1 memiliki penyimpangan bobot yang lebih banyak, hal ini diduga terjadi karena laju alir dari F1 lebih rendah dari pada F2 sehingga jumlah granul yang mengisi ruang die kurang tepat.

\section{Friabilitas}

Berdasarkan tabel diatas dapat dilihat bahwa F1 tidak memenuhi persyaratan uji friabilitas dan F2 memenuhi persyaratan uji Friabilitas. Ketidaksesuaian ini disebabkan oleh fisik tablet F1 yang tidak terkempa dengan baik sehingga menyebabkan rongga pada tablet dan menyebabkan tablet menjadi rapuh. Rongga tersebut diduga terjadi karena laju alir F1 yang lebih rendah dari pada laju alir F2 sehingga jumlah granul yang terisi kurang tepat. Syarat kerapuhan tablet tidak melebihi 1\% (Ansel, 2010). 


\section{Waktu Hancur}

Berdasarkan dilihat waktu hancur kedua tablet memenuhi persyaratan yaitu kurang dari 15 menit. Waktu hancur F2 lebih lama dibandingkan dengan F1. Menurut Prasesti,dkk (2016), kandungan amilopektin dari buah sukun berkisar antara $81,64 \%-85,67 \%$. Seharusnya semakin besar penambahan pati sukun maka semakin lambat pula waktu hancur tablet. Selain karena kandungan amilopektin hal ini juga disebabkan karena F1 memiliki fisik yang lebih rapuh sehingga daya penetrasi dan absorpsi air kedalam pori tablet lebih mudah, menyebabkan ikatan granul mudah terlepas sehingga waktu hancur tablet semakin cepat (Zobel, 1995).

\section{Penetapan Kadar Parasetamol}

Tabel 3. Penetapan kadar

\begin{tabular}{ccccc}
\hline Formula & \multicolumn{4}{c}{ Penetapan Kadar (\%) } \\
\cline { 2 - 5 } & 1 & 2 & 3 & Rata-rata \\
\hline 1 & 97,56 & 102,90 & 98.49 & 99,65 \\
2 & 102,03 & 100.98 & 101,89 & 101,63 \\
\hline
\end{tabular}

Uji penetapan kadar dilakukan untuk mengetahui kandungan zat aktif tiap tablet. Kadar zat aktif yang diterima dalam tablet parasetamol terletak pada rentang nilai 90\% - 110\%. Berdasarkan hasil yang diperoleh baik F1 maupun F2 memenuhi persyaratan kandungan zat aktif. Ada tiga faktor yang langsung dapat menimbulkan masalah keseragaman isi tablet yaitu tidak seragamnya distribusi bahan obat pada pencampuran bubuk atau granulasi, pemisahan dari campuran bubuk atau granulasi selama berbagai proses pembuatan dan penyimpangan berat tablet (Lachman, 2008).

\section{Pengujian Disolusi Tablet}

Tabel 4. Hasil Disolusi F1

\begin{tabular}{cccc}
\hline Waktu (menit) & Rata-rata absorbansi & Faktor koreksi $(\mathrm{ppm})$ & $\%$ terdisolusi $(\%)$ \\
\hline 5 & 0,473 & 375,12 & 58,00 \\
10 & 0,585 & 472,28 & 73,03 \\
15 & 0,711 & 579,78 & 89,65 \\
30 & 0,770 & 630,46 & 97,49 \\
\hline
\end{tabular}


Proses melarutnya suatu obat disebut disolusi. Uji disolusi berguna untuk mengetahui seberapa banyak obat yang melarut dalam medium asam atau basa (lambung dan usus halus) (Ansel, 2010). Tablet efektif dalam melepaskan obatnya untuk diabsorbsi tergantung pada kecepatan hancurnya dan pecahnya granul (Sinko, 2011).

Tabel 5. Hasil Disolusi F2

\begin{tabular}{cccc}
\hline $\begin{array}{c}\text { Waktu } \\
\text { (menit) }\end{array}$ & $\begin{array}{c}\text { Rata-rata } \\
\text { absorbansi }\end{array}$ & $\begin{array}{c}\text { Faktor koreksi } \\
(\mathrm{ppm})\end{array}$ & \% terdisolusi (\%) \\
\hline 5 & 0,473 & 375,12 & 55,98 \\
10 & 0,597 & 482,47 & 72,01 \\
15 & 0,713 & 581,54 & 86,79 \\
30 & 0,768 & 628,78 & 93,84 \\
\hline
\end{tabular}

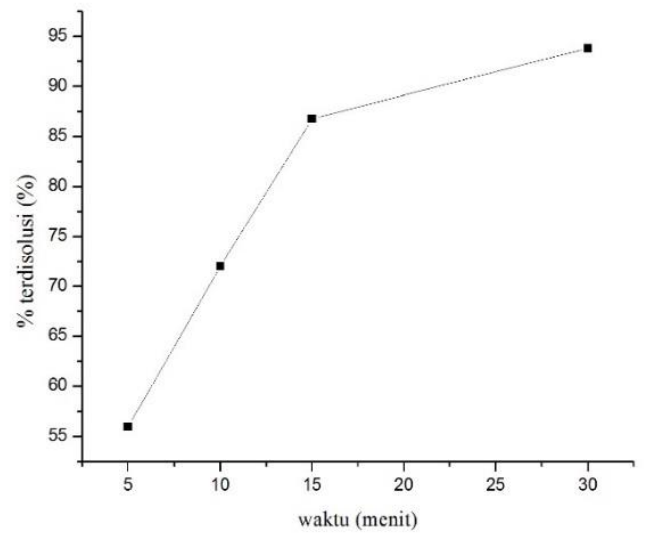

Gambar 5. Kurva Disolusi F1

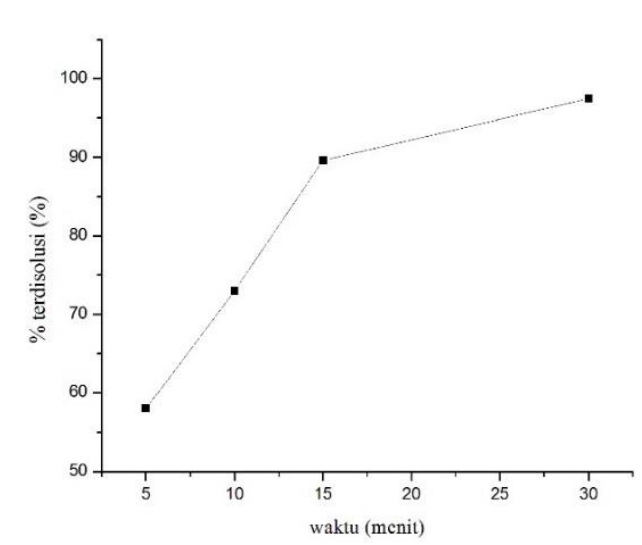

Gambar 6. Kurva Disolusi F2

Berdasarkan hasil yang diperoleh dapat dilihat semua formula tablet memenuhi persyaratan uji disolusi, dimana pada waktu 30 menit kadar parasetamol yang terlarut tidak kurang dari $80 \%$. Akan tetapi dapat dilihat pula bahwa \% disolusi F1 lebih besar dibandingkan dengan F2, hal ini disebabkan penggunaan konsentrasi pati sukun yang lebih kecil pada F1 sehingga mempengaruhi pelepasan zat aktif pada tablet. Amilopektin dengan konsentrasi yang lebih besar dapat memperlambat pelepasan zat aktif karena amilopektin didalam tablet juga berperan sebagai pengikat yang dapat menghambat pelepasan ikatan antar partikel (Maulani, 2012). 


\section{KESIMPULAN}

Pati sukun dapat diformulasikan menjadi bahan pengisi tablet. Keempat formula memenuhi persyaratan kualitas granul berupa uji laju alir, sudut istirahat, bulk dan tap density, serta uji kompresibilitas, namun tidak memenuhi uji distribusi ukuran partikel. Tablet yang dapat dikempa hanya F1 dan F2. F1 tidak memenuhi persyaratan friabilitas namun memenuhi persyaratan keseragaman ukuran dan bobot, waktu hancur, penetapan kadar serta uji disolusi. F2 memenuhi persyaratan untuk semua uji sifat fisik tablet uji penetapan kadar dan uji disolusi.

\section{DAFTAR PUSTAKA}

Ansel, H.C. 2010. Pengantar Bentuk Sediaan Farmasi Edisi IV. UI Press: Jakarta. Aulton, M. E. 2001. Pharmaceutics The Science of Dosage Form Design, Second Edition. Churchill: Livingstone.

Ditjen POM. 1979. Famakope Indonesia Edisi III. Departemen Kesehatan Republik Indonesia: Jakarta.

Ditjen POM. 1995. Farmakope Indonesia Edisi IV. Departemen Kesehatan Republik Indonesia: Jakarta.

Ditjen POM. 2015. Farmakope Indonesia Edisi V. Departemen Kesehatan Republik Indonesia: Jakarta.

Prasesti, G. K., Ardana, M., Rusli, R. (2016). Karakteristik Fisikokimia Eksipien Tablet dari Pati Sukun (Artocarpus communis). Prosiding Seminar Nasional Tumbuhan Obat Indonesia Ke-50 Tahun 2016. Halaman 204-210. https://prosiding.farmasi.unmul.ac.id/index.php/mpc/article/view/108

Lachman L., Lieberman H.A., Kanig J.L. 2008. Teori dan Praktek Farmasi Industri Edisi III. UI Press: Jakarta.

Sinko, Patrick J. 2011. Farmasi Fisika dan Ilmu Farmasetika Martin. EGC: Jakarta. Sulaiman. 2007, Teknologi \& Formulasi Sediaan Tablet. Universitas Gadjah Mada: Yogyakarta

Voigt, R. 1994. Buku Pelajaran Teknologi Farmasi. Gajah Mada University Press: Yogyakarta. 